\title{
The Operationalized Portage Inventory (OPI): Systematic Review
}

\author{
Ana Lúcia Rossito Aiello* Đ \& Lúcia Cavalcanti de Albuquerque Williams (D) \\ Universidade Federal de São Carlos, São Carlos, SP, Brasil
}

\begin{abstract}
The goal of the present paper is to systematically review the use of the Operationalized Portage Inventory (OPI) instrument to measure children's development from 0-6 years, in Brazilian publications. Using the PRISMA-P methodology, databases were assessed in Portuguese (Capes, BVS-Psychology, BVS-Bireme, Redalyc, Google Scholar) from 2002 to 2016. Forty-two studies were analyzed in terms of goals, procedures, design, results and limitations. Twelve papers were characterized as descriptive, 14 were correlational, and 16 involved intervention assessment. Studies suggested the OPI to be useful in describing and/or evaluating repertoires of 976 children with 19 different syndromes and 7 diverse risk conditions. More methodological rigor is recommended in future studies using the OPI.
\end{abstract}

KEYWORDS: child development, inventories, literature review

\section{Inventário Portage Operacionalizado (IPO): Revisão Sistemática}

\begin{abstract}
RESUMO - O objetivo do presente estudo consiste em revisar sistematicamente as publicações brasileiras envolvendo o uso do instrumento Inventário Portage Operacionalizado (IPO) para medir o desenvolvimento de crianças de 0-6 anos. Com a metodologia PRISMA-P, as bases nacionais (Periódicos Capes, BVS-Psicologia, BVS- Bireme, Redalyc, Google Acadêmico) foram revistas no período de 2002 a 2016. Quarenta e dois estudos foram analisados quanto ao objetivo, procedimento, delineamento, resultados e limitações. Doze estudos se caracterizaram como descritivos, 14 correlacionais, e 16 envolveram avaliação com intervenção. A utilidade do IPO foi demonstrada pela descrição e avaliação de repertórios de 976 crianças com 19 diferentes síndromes e em 7 condições de risco. É recomendado um maior rigor metodológico em estudos futuros com o IPO.
\end{abstract}

PALAVRAS-CHAVE: desenvolvimento infantil, inventários, revisão de literatura

The "Portage Guide to Early Education" was developed by Bluma et al. (1976) to provide services to preschool children with developmental disabilities in rural communities in Portage, Wisconsin (USA). The program is composed of (a) recommended training sessions to be done at home; (b) a "Curricular Guide" (Bluma et al., 1976) listing 580 behaviors from six developmental areas (Motor, Cognition, Socialization, Language, Self-care, and Infant Stimulation) to assess and teach children with special needs, and (c) a "Parent Behavior Inventory" (Boyd et al., 1977). The Portage Guide is currently in its third revised edition (Cooperative Educational Service Agency-5, 2015); it is used in more than 60 countries (Brue \& Oakland, 2001), having been translated and adapted into over 36 different languages (Cooperative Educational Service Agency-5, 2003).
The Portage Program does not employ its Curricular Guide as an evaluation instrument for the training conducted, opting instead to use Developmental Scales and other instruments. In this regard, the "Operationalized Portage Inventory (OPI)" was developed by Williams and Aiello (2001), adapting the Curricular Guide, thus transforming it into a reliable systematic evaluation tool of child development, useful in interventions by both parents and professionals. To this end, criteria, definitions, and specifications regarding evaluation conditions and the description of the material to be used for each of the 580 behaviors of the "Portage Guide for Pre-school Education" were proposed.

Since its publication (Williams \& Aiello, 2001), the OPI has been used in research involving dissertations and theses, in addition to being cited in books specializing in

* E-mail: analu.roaiello@gmail.com
- Submetido: 29/05/2017; Aceito: 23/01/2019. 
child intervention (Formiga et al., 2010; Gomes \& Silveira, 2016; Windholz, 2016). Rodrigues (2009) conducted a study with the main goal of comparing the behavioral repertoire of infants using the OPI. The main results showed a disadvantage in performance of premature and low birth weight when compared to the repertoire of infants born to adolescent mothers and risk-free infants. Andreucci (2013) employed the OPI to evaluate the effectiveness of a program for the development of psychomotricity and resilience in Brazilian children belonging to disadvantaged economical groups and in children from rural areas in Portugal. The results indicate superior performance in the OPI for children that attended the program, regardless of nationality, when compared to children who did not undergo the intervention.

According to Oliveira et al. (2008), the OPI was cited as being the main source for the development of the "Desenvolve ${ }^{\circledR} /$ Instrumentoavaliativo", an assessment tool to assess 19 skills involved in size perception, association of ensembles, number denomination among other skills, in children with Cerebral Palsy.
Furthermore, the OPI has been cited in papers reviewing evaluation instruments to measure child development of children aged from 0-2 years (Vieira et al., 2009), as well as high-risk infants (Rodrigues, 2012). In these reviews, the OPI is considered to be a useful and effective instrument to assess various developmental areas and age groups, enabling child development to be monitored over time. The OPI is also cited as one of five instruments that assesses "daily functional habits and self-reliance in children", used by occupational therapists in daily living activities (Silva \& Martinez, 2002). The instrument is also mentioned as a child cognitive assessment tool in a paper reviewing Brazilian scientific production in this subject (Suehiro et al., 2015), and in a systematic literature review on the relationship between prematurity, birth weight, and language development in Brazilian children (Zerbeto et al., 2015).

Considering the contributions of this instrument to the evaluation of child development, the goal of this paper is to systematically review Brazilian publications involving the use of the Operationalized Portage Inventory to measure children's development from 0-6 years.

\section{METHOD}

The review procedure was based on the PRISMA-P 2015 protocol (Preferred Reporting Items for Systematic Reviews and Meta-Analysis Protocols, Shamseer et al., 2015). It comprehends a checklist designed to ease the process of drafting and reporting a systematic review. For instance, the protocol prescribes the description of eligibility criteria, sources of information, and research strategies.

In order to be included in this review, the studies were to meet the following inclusion criteria: (a) type: scientific papers published in a peer-reviewed journal and readily available in full; (b) theme: papers that used and referenced the OPI as an instrument in the method section; (c) the paper could use one or all of the areas of developmental assessment, a single or all age groups, combined or not with other instruments; (d) time period: 2002 (one year after the 2001 publication by Williams \& Aiello) until June of 2016; and (e) language: Portuguese or English. The databases were: Capes journals, VHL-Psychology, VHLBireme, Redalyc and Google Scholar. "Operationalized Portage Inventory" was one of the keywords used, as well as three other combinations: Inventory AND Portage, Inventory AND Operationalized, and Portage AND Operationalized.

The references of the papers that met the inclusion criteria were also analyzed in order to identify other studies that had not been located within the databases. All of the papers that were found were evaluated through a reading of their title, abstract and references. The following were excluded: (a) books, book chapters, review papers and essays; (b) dissertations, theses, monographs and undergraduate term papers; (c) abstracts of oral presentations/posters, conference proceedings, symposiums and seminars; (d) repeated papers; (e) papers that did not use the OPI as a behavioral assessment tool; (f) papers that only referenced Williams and Aiello (2001), without making use of the OPI; and $(\mathrm{g})$ papers that made use of the OPI but did not reference it.

The studies included were read and summarized in terms of: (a) main objectives; (b) participant characteristics (number and diagnosis); (c) instruments used, and description of the areas, criteria, and age groups assessed with the OPI; and (d) design. In relation to the design, the studies were classified as: (a) descriptive: when the objective was to describe the children's behavioral repertoire; (b) correlational: when the study compared two or more variables, one of which was the performance in the OPI, and (c) experimental: when the performance in the OPI served as a measure to evaluate interventions. The tables were constructed based on the analysis of the studies following the established design parameters. 


\section{RESULTS}

The search for papers resulted in 264 relevant references. Google Scholar identified 190 papers and the databases comprised of Capes journals, VHL-Psychology (Pepsic and Scielo), VHL-Bireme and Redalyc found a total of 71 papers (14, 16, 24 and 17, respectively); and 3 additional articles were obtained by consulting references from relevant papers. The following studies were discarded: (a) 14 books, book chapters, review articles and essays; (b) 72 dissertations or theses, monographs and undergraduate term papers; (c) 21 abstracts of oral presentations/posters, conference or scientific meeting proceedings; and (d) 82 repeated papers. Among the remaining 75, 14 mentioned the OPI but did not use it as an assessment tool or did not reference it, and 19 papers only referenced the book or an interview guide proposed by Williams and Aiello (2001); thus, 42 studies remained.

Breaking down the 42 papers by the year of publication allowed us to observe that there were no publications in 2002, 2003, or in the first semester of 2016. Between 2004 and 2015, the publication of indexed papers was continuous, with an increase in the publishing frequency from 2009 onward. On average, 3.5 papers were published per year from 2004 to $2015(S D=2.43)$. At least 1 paper was found per year $(2005,2007,2008)$, with a maximum number of 8 (2012).

The 42 papers were published in 29 journals, 21 (72.4\%) were evaluated by the 2014 Qualis System (a Brazilian method to evaluate journals based on impact metrics) exclusively in the field of Psychology and 12 (41.3\%) in the fields of Education and Psychology. Qualis journal results ranged from $\mathrm{A} 1$ to $\mathrm{C}$. Those with the largest number of published papers were: Journal of Human Growth and Development $(N=5$, Psychology Qualis A2); Brazilian Journal of Special Education [author's translation] ( $N$ $=4$, Psychology Qualis B1) and CEFAC Journal $(N=3$, Psychology Qualis B1). Eight papers (Formiga et al., 2004; Menezes et al., 2013; Morais et al., 2012; Murta et al., 2011; Peres, 2004; Robles \& Gil, 2006; Rodrigues \& BolsoniSilva, 2011; Taques \& Rodrigues, 2006) were published in journals ranking at an A level in Psychology. Nine papers were not found in the Qualis 2014 system.

Table 1 shows a synthesis of the 12 studies that used the OPI to describe participants according to the classification of research designs found in the studies. In four of these studies the results were also used to identify prerequisite skills necessary to teach reading skills (Lorenzo et al., 2010); to select tasks (cutting, drawing, copying, stacking blocks) that were to be used in the intervention procedure aimed at reducing uncompliant behavior in children (Menezes et al., 2013); to group children as to heterogeneity degree of repertoire (children with typical development and children with developmental delay, especially with regards to Language), as well as to characterize control through instructions (Robles \& Gil, 2006) and describe the verbal repertoire (Sousa et al. , 2013).

It should be noted that while solely analyzing the objectives listed in Table 1, three studies were characterized by the authors as being experimental (Lorenzo et al., 2010; Menezes et al., 2013; Sousa et al., 2013). However, a thorough reading made it possible to identify that the OPI was used in such studies only in a descriptive manner, as previously mentioned.

According to Table 1, the OPI was applied to 150 children, $68 \%$ of which had different syndromes, disabilities, or health problems; $29.3 \%$ were low-income children, and $2.6 \%$ of the children had typical development, which demonstrates its applicability to a broad range of childhood health conditions. Some studies included all of the developmental areas of the OPI (Alves et al., 2011, Gejão et al., 2009; Postalli et al., 2011; Robles \& Gil, 2006; Rossi et al., 2009). Others used only one area: Motor Development (Almeida \& Formiga, 2010; Brito et al., 2009; Menezes et al., 2013); Language (Lorenzo et al., 2010; Sousa et al., 2013); Language and Socialization (Machado \& Bello, 2015) or Infant Stimulation (Taques $\&$ Rodrigues, 2006). Nine studies did not provide data regarding the application of the OPI, two claimed they followed the instructions contained in the manual (Almeida \& Formiga, 2010; Taques \& Rodrigues, 2006), and only one study (Brito et al., 2009) pointed out changes in the evaluation criteria of the items in relation to the suggestions contained in the manual (Williams \& Aiello, 2001). Table 1 shows that the OPI was used as the only measure (58.3\%) or integrated with other instruments, in which case the "Denver Developmental Screening Test" (Frankenburg, et al., 1999/2018) was the most used one (Gejão et al., 2009; Sousa et al., 2013). Most of the studies were carried out in family households and philanthropic institutions. None of the studies brought forth criticism towards the OPI.

Table 2 shows the 14 studies in which performance in the OPI was used to compare (or correlate) other variables. Six hundred and ten children with different risks factors (prematurity, low birth weight, high lead blood levels, nutritional condition, children of adolescent mothers), typical development and disabilities (blindness, holoprosencephaly, cerebral palsy) had their performance in the OPI correlated to variables, such as maternal anxiety and stress with the child's performance in several different Infant Stimulation programs or compared to each other. One of the studies made use of the Infant Stimulation area by comparing the performance of premature infants, those with low birth weight, and infants born to an adolescent mother (Almeida et al., 2012), and a second study, despite having evaluated all of the areas, presented data only on Motor Development correlating it to the mother's age, the parents' educational level, mother's health condition during 
Table 1

Studies in which the OPI was used to Describe the Developmental Repertoire

\begin{tabular}{|c|c|c|c|c|c|}
\hline Author(s) & Objective & Instruments & Diagnosis/Risk & $\mathbf{n}$ & $\begin{array}{l}\text { Data Collection } \\
\text { Site }\end{array}$ \\
\hline $\begin{array}{l}\text { Almeida \& } \\
\text { Formiga, } \\
2010\end{array}$ & To analyze gross/fine motor skills & OPI (M, 5-6 years) & Williams Syndrome & 1 & $\begin{array}{l}\text { Home } \\
\text { Playground }\end{array}$ \\
\hline $\begin{array}{l}\text { Alves et al., } \\
\quad 2011\end{array}$ & $\begin{array}{l}\text { To describe neurofunctional profile, asses } \\
\text { developmental evolution }\end{array}$ & OPI, GMGCS & Generic syndromes & 5 & $\begin{array}{c}\text { Pestalozzi } \\
\text { Association, Goiás } \\
\text { State }\end{array}$ \\
\hline $\begin{array}{l}\text { Brito et al., } \\
\quad 2009\end{array}$ & Assess bodily-kinesthetic profile & $\begin{array}{l}\text { OPI (M-10 items, 5-6 years), } \\
\text { Bruininks-Ozeretsky }\end{array}$ & Down Syndrome & 20 & Tocantins State \\
\hline $\begin{array}{l}\text { Gejão et al., } \\
2009\end{array}$ & $\begin{array}{l}\text { To describe psycholinguistic and } \\
\text { communicative skills }\end{array}$ & $\begin{array}{l}\text { OPI, ELMS, PPVT, GABDS, } \\
\text { LDES, DDST-II, ABFW, } \\
\text { ITPA, OCB }\end{array}$ & $\begin{array}{l}\text { Phenylketonuria } \\
\text { Congenital } \\
\text { hypothyroidism }\end{array}$ & $\begin{array}{l}25 \\
43\end{array}$ & $\begin{array}{l}\text { APAE Association, } \\
\text { Bauru, São Paulo } \\
\text { State }\end{array}$ \\
\hline $\begin{array}{l}\text { Lorenzo et } \\
\text { al., } 2010\end{array}$ & $\begin{array}{l}\text { To teach a young woman basic behaviors } \\
\text { for reading acquisition skills }\end{array}$ & $\begin{array}{l}\text { OPI ( } \mathrm{L} \text { and "reading } \\
\text { behavior") }\end{array}$ & Intellectual disability & 1 & $\begin{array}{l}\text { Public school } \\
\text { Florianopolis, Santa } \\
\text { Catarina State }\end{array}$ \\
\hline $\begin{array}{l}\text { Machado \& } \\
\text { Bello, } 2015\end{array}$ & $\begin{array}{l}\text { To identify social and shared attention } \\
\text { skills }\end{array}$ & $\begin{array}{l}\text { OPI (some items from } \mathrm{L}, \mathrm{S}, \\
1-2 \text { years) }\end{array}$ & $\begin{array}{l}\text { Mother-baby dyad } \\
\text { Typical development }\end{array}$ & 4 & Home \\
\hline $\begin{array}{l}\text { Menezes et } \\
\text { al., } 2013\end{array}$ & $\begin{array}{l}\text { To evaluate the effect of parental } \\
\text { attention and task difficulty on children's } \\
\text { uncompliant behavior }\end{array}$ & OPI (M, 3-6 years) & $\begin{array}{l}\text { Mother-child dyads } \\
\text { with atopic dermatitis }\end{array}$ & 5 & - \\
\hline $\begin{array}{l}\text { Postalli et al., } \\
\quad 2011\end{array}$ & $\begin{array}{l}\text { To describe a family exposed to multiple } \\
\text { stressors and their impact on development }\end{array}$ & OPI & Developmental delay & 1 & Home \\
\hline $\begin{array}{l}\text { Robles \& Gil, } \\
\quad 2006\end{array}$ & $\begin{array}{l}\text { To characterize the acquisition and } \\
\text { development of instructional control }\end{array}$ & OPI & Low income & 3 & $\begin{array}{l}\text { Philanthropic Day } \\
\text { Care, São Paulo } \\
\text { State }\end{array}$ \\
\hline $\begin{array}{l}\text { Rossi et al., } \\
\quad 2009\end{array}$ & $\begin{array}{l}\text { To present a case and review clinical } \\
\text { findings that focus on language, } \\
\text { cognition, and deglutition }\end{array}$ & OPI (L) & $\begin{array}{l}\text { Oropharyngeal } \\
\text { dysphagia }\end{array}$ & 1 & - \\
\hline $\begin{array}{l}\text { Sousa et al., } \\
2013\end{array}$ & $\begin{array}{l}\text { To investigate procedures to improve } \\
\text { listening skills }\end{array}$ & OPI (L), DDST-II & $\begin{array}{l}\text { Low-income } \\
\text { infant }\end{array}$ & 1 & $\begin{array}{l}\text { Philanthropic day } \\
\text { care }\end{array}$ \\
\hline $\begin{array}{l}\text { Taques \& } \\
\text { Rodrigues, } \\
2006\end{array}$ & $\begin{array}{l}\text { To assess infant development during the } \\
\text { first } 4 \text { months of life }\end{array}$ & OPI (IS) & Low-income infant & 40 & $\begin{array}{l}\text { UNESP, } \\
\text { Bauru, São Paulo } \\
\text { State }\end{array}$ \\
\hline $\begin{array}{l}\text { Total number } \\
\text { of children }\end{array}$ & & & & 150 & \\
\hline
\end{tabular}

Note.GMFCS= Gross Motor Function Classification System; ELMS= Early Language Milestone Scale; PPVT= Peabody Picture Vocabulary Test; GABDS= Gesell and Amatruda's Behavioral Development Scale; LDES= Language Developmental Screening Test; DDST-II= Denver Developmental Screening Test; ABFW= Child Language Test-phonology; ITPA= Illinois Test of Psycholinguistic Abilities; OCB= Observation Communication Behavior; $\mathrm{D}=$ Motor Development; IS= Infant Stimulation; $\mathrm{L}=$ Language; $\mathrm{S}=$ Socialization.

pregnancy, gestational age, and birth condition (Pereira, Rodrigues et al., 2015).

The remaining studies evaluated all of the areas of the OPI. One of the studies (Gejão \& Lamônica, 2008) assessed children's performance in the OPI areas to their performance on the scale Early Language Milestone Scale, (Coplan, 1993). Six studies (Almeida et al., 2012; Lamônica \& Picolini, 2009; Pereira, Silva-Marinho et al., 2015; Rodrigues \& Bolsoni-Silva, 2011; Rodrigues \& Carnier, 2007; Rodrigues \& Nunes, 2009) applied the OPI in accordance with the Manual's description (Williams \& Aiello, 2001). França-Freitas and Gil's (2012) study applied the OPI items through an interview with parents and teachers and adapted some items from all areas in order to accommodate blind children. The most common intervention places were university centers or laboratories (Almeida et al., 2012; Pereira et al., 2014; Pereira, Rodrigues et al., 2015; Pereira, Silva-Marinho et al., 2015; Rodrigues \& Bolsoni-Silva, 2011; Rodrigues \& Carnier, 2007; Rodrigues \& Nunes, 2009) and the Pestalozzi Association (Alves et al., 2012; Morais et al., 2012). The compilation of these studies (Table 2) does not allow to identify a pattern of results, as the authors used different variables to correlate to the behavioral repertoire measured with the OPI: distinct number of children, of age and diagnosis, as well as varied statistical analyzes.

Table 3 shows the results from studies that used the OPI to assess children's repertoires after an intervention. A total of 212 children ranging from $0-7$ years old participated in these studies. The authors identified the existence of 
Table 2

Studies in which the OPI was used to Compare or Correlate Variables

\begin{tabular}{|c|c|c|c|c|c|}
\hline Author(s) & Objective & Instruments & Diagnosis/risk & $\mathbf{n}$ & Collection site \\
\hline Almeida et al., 2012 & $\begin{array}{l}\text { To assess infant development by } \\
\text { comparing risk and gender }\end{array}$ & OPI (IS) & $\begin{array}{l}\text { Premature } \\
\text { Low birth weight } \\
\text { Adolescent mothers }\end{array}$ & $\begin{array}{l}24 \\
21 \\
55\end{array}$ & $\begin{array}{l}\text { State University, Bauru, } \\
\text { São Paulo State }\end{array}$ \\
\hline Alves et al., 2012 & $\begin{array}{l}\text { To correlate profile characteristics with } \\
\text { motor development }\end{array}$ & OPI, GMGCS & Generic syndromes & 13 & $\begin{array}{c}\text { Pestalozzi Association, } \\
\text { Goiás State }\end{array}$ \\
\hline Cassab et al., 2012 & $\begin{array}{l}\text { To compare performance of } \\
\text { developmental skills }\end{array}$ & OPI & $\begin{array}{l}\text { Holoprosencephaly } \\
\text { Holoprosencephaly- } \\
\text { like }\end{array}$ & $\begin{array}{l}2 \\
8\end{array}$ & - \\
\hline $\begin{array}{l}\text { França-Freitas \& Gil, } \\
\qquad 2012\end{array}$ & $\begin{array}{l}\text { To compare the performance of } \\
\text { children who received different } \\
\text { stimulationwith development }\end{array}$ & OPI & $\begin{array}{l}\text { Blind } \\
\text { Seers }\end{array}$ & $\begin{array}{l}2 \\
2\end{array}$ & Public Schools \\
\hline $\begin{array}{c}\text { Gejão \& } \\
\text { Lamônica,2008 }\end{array}$ & $\begin{array}{l}\text { To outline a developmental profile } \\
\text { establishing influences of the medical } \\
\text { history }\end{array}$ & OPI, ELMS & $\begin{array}{c}\text { Congenital } \\
\text { hypothyroidism }\end{array}$ & 35 & $\begin{array}{l}\text { Newborn screening } \\
\text { center, São Paulo State }\end{array}$ \\
\hline $\begin{array}{l}\text { Lamônica \& Picolini, } \\
2009\end{array}$ & $\begin{array}{l}\text { To assess performance of } \\
\text { developmental skills }\end{array}$ & OPI ( $0-2$ years $)$ & Premature & 30 & São Paulo State \\
\hline Morais et al., 2012 & $\begin{array}{l}\text { To assess the correlation between } \\
\text { neurofunctional profile andmotor skills }\end{array}$ & OPI, GMGCS & Cerebral palsy & 27 & $\begin{array}{c}\text { Pestalozzi Association, } \\
\text { Goiás State }\end{array}$ \\
\hline Murta et al., 2011 & $\begin{array}{l}\text { To evaluate the development and } \\
\text { nutritional condition of children aged } \\
0-6\end{array}$ & OPI & Poverty & 48 & $\begin{array}{l}\text { Home, Minas Gerais } \\
\text { State }\end{array}$ \\
\hline Pereira et al.,2014 & $\begin{array}{l}\text { To correlate the performance of infants } \\
\text { with maternal variables (anxiety and } \\
\text { stress), as well as sociodemographic } \\
\text { variables }\end{array}$ & OPI & $\begin{array}{c}- \\
\text { (Typical development) }\end{array}$ & 16 & $\begin{array}{l}\text { Mato Grosso do Sul } \\
\text { State }\end{array}$ \\
\hline Pereira et al., 2015a & $\begin{array}{l}\text { To compare and correlate maternal } \\
\text { stress and anxiety levels with infant } \\
\text { development }\end{array}$ & OPI & $\begin{array}{c}- \\
\text { (Typical development) }\end{array}$ & 16 & $\begin{array}{c}\text { Mato Grosso do Sul } \\
\text { State }\end{array}$ \\
\hline Pereira et al., 2015b & $\begin{array}{l}\text { To correlate the motor development of } \\
\text { nursling infants with maternal variables } \\
\text { and birth conditions }\end{array}$ & OPI (M, 0-1 years) & $\begin{array}{c}- \\
\text { (Typical development) }\end{array}$ & 57 & $\begin{array}{l}\text { Mato Grosso do Sul } \\
\text { State }\end{array}$ \\
\hline $\begin{array}{l}\text { Rodrigues \& Bolsoni- } \\
\quad \text { Silva,2011 }\end{array}$ & $\begin{array}{l}\text { To correlate the development of } \\
\text { nursling infants } \\
\text { to premature birth }\end{array}$ & OPI & $\begin{array}{c}\text { Premature } \\
\text { (Typical development) }\end{array}$ & $\begin{array}{l}74 \\
56\end{array}$ & São Paulo State \\
\hline $\begin{array}{l}\text { Rodrigues \& Carnier, } \\
2007\end{array}$ & $\begin{array}{l}\text { To assess development compared with } \\
\text { lead contamination levels }\end{array}$ & OPI & $\begin{array}{l}\text { Blood lead level } \\
\text { above } 10 \mu \mathrm{g} / \mathrm{dl}\end{array}$ & 60 & $\begin{array}{l}\text { State University, Bauru, } \\
\text { São Paulo State }\end{array}$ \\
\hline $\begin{array}{l}\text { Rodrigues \& Nunes, } \\
2009\end{array}$ & $\begin{array}{l}\text { To describe development by age and } \\
\text { gender, comparing delays in each area } \\
\text { with the level of lead }\end{array}$ & OPI & $\begin{array}{l}\text { Blood lead level } \\
\text { above } 10 \mu \mathrm{g} / \mathrm{dl}\end{array}$ & 64 & $\begin{array}{l}\text { State University, Bauru, } \\
\text { São Paulo State }\end{array}$ \\
\hline $\begin{array}{l}\text { Total number of } \\
\text { children }\end{array}$ & & & & 610 & \\
\hline
\end{tabular}

Note. GMFCS= Gross Motor Function Classification System; ELMS= Early Language Milestone Scale; M= Motor Development.

developmental risk factors for 175 of the children (e.g., adolescent mother, prematurity, malnutrition, and attending daycare centers for low-income children) and 37 children had previously been diagnosed with different syndromes / disorders (e.g., Down Syndrome, Cerebral Palsy, Treacher Collins Syndrome, Lennox Gastaud, Autistic Spectrum Disorder). As for the design parameters, 14 studies (87.50\%) can be considered as pre-experimental as there may be opposing explanatory hypotheses regarding the changes that occurred following the intervention. Only two studies (Cró \& Andreucci, 2014; Formiga et al., 2004) employed a group design (experimental group x control group). However, in all of the studies the samples were formed based on convenience and none of them reported the reliability of OPI assessments. All 16 studies showed results that were favorable regarding the children's development after an intervention based on the OPI.

The number of sessions and the duration of the intervention was reported in 10 studies, ranging from nine 90-minute sessions (Cia et al., 2005) to 30 to 50-minute sessions (Taira et al., 2009). In 11 of the studies there was no information on how to apply the OPI. Silva et al. (2009) reported having followed the application criteria as recommended by the OPI authors, and 4 studies altered the 
OPI's application method (Branquinho et al., 2014; Formiga et al., 2004; Prado et al., 2012; Sandroni et al., 2015). In the studies shown on Table 3, different locations were used for the deployment of the OPI and none of the studies reported the involvement of family members such as siblings and grandparents.

Table 3

Studies in which the OPI was used to Evaluate the Repertoire after an Intervention

\begin{tabular}{|c|c|c|c|c|c|}
\hline Author(s) & Objective & Instruments & Diagnosis/risk & $\mathbf{n}$ & Data Collection Site \\
\hline $\begin{array}{l}\text { Anunciação et al., } \\
2015\end{array}$ & $\begin{array}{l}\text { To assess motor performance (pre and } \\
\text { post intervention) }\end{array}$ & OPI (M, 3-4 years) & Down Syndrome & 1 & Preschool \\
\hline $\begin{array}{l}\text { Branquinho et al., } \\
2014\end{array}$ & $\begin{array}{l}\text { To assess development evolution (pre } \\
\text { and post intervention) }\end{array}$ & OPI & $\begin{array}{l}\text { Generic and/ } \\
\text { or malformative } \\
\text { syndromes }\end{array}$ & 10 & $\begin{array}{l}\text { Pestalozzi Association, } \\
\text { Goiás State }\end{array}$ \\
\hline $\begin{array}{c}\text { Capalonga \& Grave, } \\
2012\end{array}$ & $\begin{array}{l}\text { To assess the effect of the stimulation } \\
\text { program (pre and post intervention) }\end{array}$ & OPI & $\begin{array}{l}\text { Global } \\
\text { neuropsychomotor } \\
\text { delay }\end{array}$ & 1 & $\begin{array}{l}\text { Philanthropic Institution, } \\
\text { Rio Grande do Sul State }\end{array}$ \\
\hline Cia et al., 2005 & $\begin{array}{l}\text { To assess the impact of the intervention } \\
\text { (pre and post intervention) }\end{array}$ & OPI & Adolescent mother & 1 & Home \\
\hline $\begin{array}{l}\text { Cró \& Andreucci, } \\
2014\end{array}$ & $\begin{array}{l}\text { To assess whether or not the intervention } \\
\text { promoted development (group design) }\end{array}$ & OPI & $\begin{array}{l}\text { Malnutrition, family- } \\
\text { related stress, poverty }\end{array}$ & 151 & - \\
\hline Formiga et al., 2004 & $\begin{array}{l}\text { To evaluate the effectiveness of } \\
\text { intervention with and without training } \\
\text { of mothers in infant development (group } \\
\text { design) }\end{array}$ & OPI & Premature & 8 & $\begin{array}{l}\text { Physiotherapy Branch, } \\
\text { Federal University of } \\
\text { São Carlos, São Paulo } \\
\text { State }\end{array}$ \\
\hline $\begin{array}{c}\text { Martins \& } \\
\text { Kortmann, } 2015\end{array}$ & $\begin{array}{l}\text { To assess early stimulation in a systemic } \\
\text { psychoeducational approach (pre and } \\
\text { post intervention) }\end{array}$ & OPI & $\begin{array}{l}\text { Autistic Spectrum } \\
\text { Disorder }\end{array}$ & 1 & - \\
\hline $\begin{array}{l}\text { Nicolielo et al., } \\
2014\end{array}$ & $\begin{array}{l}\text { To describe the speech therapy } \\
\text { intervention } \\
\text { (pre and post intervention) }\end{array}$ & $\begin{array}{l}\text { IPO, ELMS, } \\
\text { GABDS }\end{array}$ & $\begin{array}{l}\text { Global developmental } \\
\text { delay }\end{array}$ & 1 & $\begin{array}{l}\text { Speech Therapy School } \\
\text { Clinic }\end{array}$ \\
\hline Peres, 2004 & $\begin{array}{l}\text { To use play situations to stimulate } \\
\text { cognitive and motor development (pre } \\
\text { and post intervention) }\end{array}$ & OPI & Cerebral Palsy (CP) & 7 & $\begin{array}{l}\text { Special needs children's } \\
\text { school, Cascavel, Paraná } \\
\text { State }\end{array}$ \\
\hline Prado et al., 2012 & $\begin{array}{l}\text { To assess growth and development and } \\
\text { intervene in motor development (pre and } \\
\text { post intervention) }\end{array}$ & OPI & Poverty & 15 & Daycare \\
\hline $\begin{array}{l}\text { Rodrigues et al., } \\
\quad 2015\end{array}$ & $\begin{array}{l}\text { To present the evolution of motor } \\
\text { function and psychomotor development } \\
\text { during rehabilitation (pre and post } \\
\text { intervention) }\end{array}$ & OPI, GMFM & $\begin{array}{l}\text { Treacher Syndrome- } \\
\text { Collins }\end{array}$ & 1 & $\begin{array}{l}\text { Pestalozzi Association, } \\
\text { Goiás State }\end{array}$ \\
\hline Sandroni et al., 2015 & $\begin{array}{l}\text { To assess psychomotor profile in a brief } \\
\text { psychomotor intervention (pre and pos) }\end{array}$ & $\begin{array}{l}\text { MDS, OPI (S, C, L } \\
\text { e SC, 5-6 years). }\end{array}$ & $\begin{array}{c}\text { TEA } \\
\text { DI } \\
\text { Atypical development }\end{array}$ & $\begin{array}{l}2 \\
1 \\
2\end{array}$ & $\begin{array}{l}\text { Multipurpose resource } \\
\text { room of a public school }\end{array}$ \\
\hline Scalha et al., 2010 & $\begin{array}{l}\text { To assess the influence of play family } \\
\text { activities on psychomotor development } \\
\text { (pre and post) }\end{array}$ & OPI & $\begin{array}{c}\mathrm{CP} \\
\text { Down Syndrome }\end{array}$ & $\begin{array}{l}2 \\
1\end{array}$ & - \\
\hline Silva et al., 2009 & $\begin{array}{l}\text { To present the evolution of gross motor } \\
\text { functioning and development after } \\
\text { rehabilitation (pre and post) }\end{array}$ & OPI, GMFM & $\begin{array}{l}\text { Lennox-Gastaud } \\
\text { Syndrome }\end{array}$ & 1 & $\begin{array}{l}\text { Pestalozzi Association, } \\
\text { Goiás State }\end{array}$ \\
\hline Silva \& Aiello, 2012 & $\begin{array}{l}\text { To assess if intervention to fathers alters } \\
\text { patterns of interactions with infant (pre } \\
\text { and post) }\end{array}$ & OPI & Down Syndrome & 5 & Household \\
\hline Taira et al., 2009 & $\begin{array}{l}\text { To present case study of a child } \\
\text { submitted to a psychomotor re-education } \\
\text { program (pre and post) }\end{array}$ & OPI & $\begin{array}{l}\mathrm{CP} \text { associated with } \\
\text { low sight }\end{array}$ & 1 & $\begin{array}{l}\text { UNESP, Presidente } \\
\text { Prudente, São Paulo } \\
\text { State }\end{array}$ \\
\hline $\begin{array}{l}\text { Total number of } \\
\text { children }\end{array}$ & & & & 212 & \\
\hline
\end{tabular}

Note. ELMS= Early Language Milestone Scale; GABDS= Gesell and Amatruda's Behavioral Development Schedules; GMFM= Gross Motor Function Measure; MDS= Motor Development Scale; $\mathrm{S}=$ Socialization; $\mathrm{C}=$ Cognition; $\mathrm{L}=$ Language; $\mathrm{SC}=$ Self-care; $\mathrm{M}=$ Motor Development. 


\section{DISCUSSION}

There is a considerable degree of heterogeneity among the 42 studies which involved a total of 972 participants of both sexes, aged 0-14 years old. Most of the participants were found to be at risk, followed by participants with 19 different syndromes. The locations designated for the application of the instrument were diverse and involved studies from 8 different Brazilian states. The results seem to suggest that the OPI is useful in evaluating the behavioral repertoire of children within a wide range of syndromes or risk conditions and disabilities, in addition to children with typical development; they also suggest that the OPI is useful to measure intervention outcomes, thus broadening the findings of previous reviews regarding developmental instruments (Rodrigues, 2012; Silva \& Martinez, 2002; Suehiro et al., 2015; Zerbeto et al., 2015). When children and adolescents over the age of 6 were evaluated with the OPI (age limit proposed by the inventory), the authors justified themselves by stating that the participants' repertoires were hindered. An alternative would have been to use a second instrument, suitable for the target age group. However, one has to bear in mind that there is a limited number of instruments to assess the behavioral repertoire of children over 6 years old. For instance, there are only five instruments listed in Brazil's Federal College of Psychology's website (SATEPsi) to assess adolescents and they target areas beyond development, such as stress, social skills, personality, and perception of social support).

In this sense, there is an interesting effort using the Portage Guide to evaluate the repertoire above the specified age range. Arvio et al. (1993) made use of the Portage Guide by Bluma et al. (1976) to describe the repertoire of 114 people with mental disabilities and degenerative diseases (ages ranging from 1 to 56 years). The authors applied different tests, in addition to the Portage Guide, and correlated the results with the performance of 30 children with typical development. The authors contend that it is possible to use the Portage Guide by Bluma et al., (1976) on clinical patients over 6 years of age, especially if the functional behavioral repertoire of these individuals is around 3-5 years old.

Nine studies reported having followed the guidelines contained in the Williams and Aiello Manual (2001) for the application of the OPI, 23 did not report how the application took place, and 10 studies indicated they had carried out adaptations. The modifications in the criteria and in the application format of the OPI were: (a) to speed up the application by requiring, for instance, that only one and not three answers should be given by the child for each one of the items evaluated (e.g., Murta et al., 2011); (b) evaluate only the age group corresponding to the child's chronological age (Alves et al., 2012; Sandroni et al., 2015); (c) to select items from a specific developmental area (e.g., Brito, et al., 2009; Formiga et al., 2004); and (d) to employ an abbreviated procedure to record the child's performance by classifying it as above, below, or in the average of what is expected (Cassab et al., 2012). The description provided by other studies did not provide clarity regarding the changes made (Branquinho et al., 2014; Gejão \& Lamônica, 2008; Prado et al., 2012).

Changes in the evaluation criteria for the OPI items proposed by Williams and Aiello (2001) that are unaccompanied by studies that substantiate them may make comparisons between studies unfeasible. Regardless of the differences in procedures and designs, all of the studies have shown satisfactory results with the use of OPI and none of them have directed criticism towards it. Nevertheless, many of the studies devoted to interventions presented a questionable level of evidence due to methodological limitations, presence of pre-experimental designs that enable explanations brought forth by rival hypotheses, such as maturation, life history, among others. The methodological frailty surrounding the scientific output in theSpecial Education field was also pointed out by Glat et al. (2014).

Since Williams' initial study (1983) with the OPI, science has progressed towards more demanding criteria with regard to evidence-based practices; studies with comparative groups with randomized clinical trials are currently held as the gold standard (Kazdin, 2003). Therefore, despite clinical improvement, the lack of experimental studies with the OPI involving large samples and occurring in natural settings (family homes, schools, or in the community), with the involvement of different family members (parents, brothers, and grandparents), still jeopardizes statements made regarding the effectiveness of the interventions reviewed in the present study.

Studies concerning the revision of instruments outline criticism towards the OPI in the sense that it is not a standardized instrument (Vieira et al., 2009), or that it does not present performance guidelines based on age (Rocha et al., 2013). However, it should be noted that the OPI is a behavioral inventory not a developmental scale. It was translated, adapted, and operationalized in the late 1970s when the criteria and requirements of psychometrics were different. Further studies with the specific purpose of conducting psychometric assessments of the OPI are recommended, such as the examination of evidence of convergent validity comparing the OPI with instruments that use normative standards, such as the Denver II (Frankenburg et al., 1999/2018).

It is worth recalling the OPI is a checklist which lists behavioral skills that the child displays at a given time, during specific tasks, based on developmental milestones and on extensive literature regarding these milestones (see Williams \& Aiello, 2001). Therefore, the OPI does not provide for classifications of the child's repertoire, 
nor should it in itself provide a diagnosis. In terms of behavioral skills found to be lacking in the children's repertoire, the results are intended for the planning of interventions. In this regard the OPI can be considered a curriculum-based-assessment).

This systematic review shows that the OPI offers data that is significant in the description, planning, monitoring, intervention and assessment of child development. Nevertheless, one limitation must be addressed: although this review was systematic, analysis and data collection were not performed by independent evaluators. In addition, we suggest that future reviews could include unpublished works, as monographs, theses or dissertations.

Considering that the OPI is an instrument that evaluates 580 behaviors and whose application may therefore require lengthy periods of time, it is suggested that interested researchers could seek out possible time reduction strategies. It would also be valid for future studies to expand the use of OPI to other environments, such as schools, daycare centers, health centers, and communities, with a greater number of children and the involvement of teachers, parents, and family members.

\section{REFERENCES}

Almeida, C. G. M., Rodrigues, O. M. P. R., \& Salgado, M. H. (2012). Diferenças no desenvolvimento de meninos e meninas em condições de risco. Boletim de Psicologia, 62(136), 1-14. http:// pepsic.bvsalud.org/scielo.php?script=sci_arttext\&pid=S0006$59432012000100002 \& \operatorname{lng}=$ pt\&tlng $=$ pt

Almeida, M. M., \& Formiga, C. K. M. R. (2010). Avaliação da motricidade ampla e fina na Síndrome de Williams: Relato de caso. Motriz: Revista de Educação Física, 16(4), 913-919. http://dx.doi.org/10.5016/1980-6574.2010v16n4p913

Alves, A. P. V., Formiga, C. K. M. R., \& Viana, F. P. (2011). Perfil e desenvolvimento de crianças com síndromes genéticas em tratamento multidisciplinar. Revista Neurociências, 19(2), 284293. http://www.revistaneurociencias.com.br/edicoes/2011/ RN1902/relato\%20de\%20caso\%2019\%2002/467\%20 relato $\% 20 \mathrm{de} \% 20$ caso.pdf

Alves, A. P. V., Formiga, C. K. M. R., \& Viana, F. P. (2012). Correlação entre as características do perfil e desenvolvimento sensório-motor de crianças com síndromes genéticas. Revista Eletrônica de Enfermagem, 14(2), 322-329. https://doi. org/10.5216/ree.v14i2.10883

Andreucci, L. C. (2013). Psicomotricidade e resiliência em crianças brasileiras e portuguesas: Um estudo comparativo para a melhoria no ensino-aprendizagem [Tese de doutorado, Universidade de Aveiro]. Repositório Institucional da Universidade de Aveiro. https://ria.ua.pt/handle/10773/1022.

Anunciação, L. M. R. L., Costa, M. P. R., \& Denari, F. E. (2015). Educação infantil e práticas pedagógicas para o aluno com Síndromede Down: O enfoque no desenvolvimento motor. Revista Brasileira de Educação Especial, 21(2), 229-244. http://dx.doi.org/10.1590/S1413-65382115000200005

Arvio, M., Hautamãki, J., \& Tiilikka, P. (1993). Reliability and validity of the Portage assessment scale for clinical studies of mentally handicapped populations. Child: Care, Health and Development, 19(2), 89-98. http://onlinelibrary.wiley.com/ doi/10.1111/j.1365-2214.1993.tb00716.x/epdf

Bluma, S., Shearer, M., Frohman, A., \& Hilliard, J. (1976). Portage Guide to Early Education (Rev. Ed.). Cooperative Educational Service Agency 12.

Boyd, R. D., Stauber, K. A., \& Bluma, S. (1977). Portage Parent Program: Instructor's Manual. Cooperative Educational Service Agency 12.

Branquinho, K. W., Amaral, L. E. F., Fagundes, R. R., \& Formiga, C. K. M. R. (2014). Evolução do desenvolvimento de crianças com síndromes genéticas e mal formativas do sistema nervoso central. Revista Movimenta, 7(2), 689-699. https://www.revista. ueg.br/index.php/movimenta/article/view/6272

Brito, A., Silva, I. L., Cardoso, F., \& Beresford, H. (2009). Avaliação do perfil cinestésico-corporal de crianças com Síndrome de Down: um parâmetro para se atender à proposta das Diretrizes Curriculares Nacionais para a educação especial. Ensaio: Avaliação e Politicas Públicas em Educação, 17(63), 341-354. http://dx.doi.org/10.1590/ S0104-40362009000200008

Brue, A. W., \& Oakland, T. (2001). The Portage Guide to Early Intervention: An evaluation of published evidence. School Psychology International, 22(3), 243-252. doi: 10.1177/0143034301223001

Capalonga, D., \& Grave, M. T. Q. (2012). Evolução psicomotora de lactente com atraso no desenvolvimento psicomotor a partir de uma intervenção em estimulação precoce: Um estudo de caso. Caderno Pedagógico, 9(2), 59-71. http://www.univates. br/revistas/index.php/cadped/article/view/857

Cassab, T. V., Lamônica, D. A. C., Zorzetto, N. L., \& Giacheti, C. M. (2012). Perfil de habilidades do desenvolvimento em crianças com holoprosencefalia e holoprosencefalialike. Revista CEFAC, 14(3), 423-429. http://dx.doi.org/10.1590/ S1516-18462011005000109

Cooperative Educational Service Agency-5 (2003). Portage Guide Birth to Six: User's Guide. https://the-portage-project. myshopify.com/products/portage-guide-3-preschoolercomplete-kit-english

Cooperative Educational Service Agency-5. (2015). Portage Guide 3. https://the-portage-project.myshopify.com/collections/ portage-guide- 3

Cia, F., Williams, L. C. A., \& Aiello, A. L. R. (2005). Intervenção focada na família: Um estudo de caso com mãe adolescente e criança de risco. Revista Brasileira de Educação Especial, 11(1), 49-66.

Coplan, J. (1993). Early Language Milestone Scale. ProEd.

Cró, M. L., \& Andreucci, L. (2014). Resiliência e psicomotricidade na educação pré-escolar: Um estudo com crianças brasileiras sócio, cultural e economicamente desfavorecidas. Omnia, 1, 45-54. https://www.grei.pt/OMNIA/OMNIA1.pdf\#page=45

Formiga, C. K. M. R., Pedrazzani, E. S., \& Tudella, E. (2010). Intervenção precoce com bebês de risco. Editora Atheneu.

Formiga, C. K., Pedrazzani, E. S., Silva, F. P. S., \& Lima, C. D. (2004). Eficácia de um programa de intervenção precoce com bebês pré-termo. Paidéia (Ribeirão Preto), 14(29), 301-311. http://dx.doi.org/10.1590/S0103-863X2004000300006

França-Freitas, M. L. P., \& Gil, M. S. C.A. (2012). O desenvolvimento de crianças cegas e de crianças videntes. Revista Brasileira de Educação Especial, 18(3), 507-526. http://dx.doi.org/10.1590/ S1413-65382012000300010

Frankenburg, W. K., Dodds, J. B., Archer, P., Bresnick, B., Mashka, P., Edelman, N., \& Shapiro, H. (1999/2018). Manual de treinamento do teste de triagem de desenvolvimento de Denver II.Hogrefe.

Gejão, M. G., Ferreira, A. T., Silva, G. K., Anastácio-Pessan, F. L., \& Lamônica, D. A. C. (2009). Communicative and psycholinguistic abilities in children with phenylketonuria 
and congenital hypothyroidism. Journal of Applied Oral Science, 17(spe), 69-75. http://dx.doi.org/10.1590/S167877572009000700012

Gejão, M. G., \& Lamônica, D. A. C. (2008). Habilidades do desenvolvimento em crianças com hipotireoidismo congênito: Enfoque na comunicação. Pró-Fono Revista de Atualização Científica, 20(1), 25-30. http://dx.doi.org/10.1590/S010456872008000100005

Glat, R., Omote, S., \& Pletsch, M. D. (2014). Análise crítica da produção do conhecimento em Educação Especial. In S. Omote, A. A. S. de Oliveira, \& M. C. M. Chacon (Orgs.), Ciência e conhecimento em Educação Especial (pp.25-44). Marquezine \& Manzini; ABPEE.

Gomes, C. G. S., \& Silveira, A. D. (2016). Ensino de habilidades básicas para pessoas com autismo: Manual para intervenção comportamental intensiva. Appris Editora.

Kazdin, A. E. (2003). Research design in clinical psychology (4th ed.). Allyn and Bacon.

Lamônica, D. A. C., \& Picolini, M. M. (2009). Habilidades do desenvolvimento de prematuros. Revista CEFAC, 11 (Supl 2), 145-153. http://dx.doi.org/10.1590/S151618462009005000019

Lorenzo, F. M., Kawasaki, H. N., \& Kubo, O. M. (2010). Programa para ensino de comportamentos de autocuidados, cognitivos e sociais para jovem com necessidades especiais. Extensio: Revista Eletrônica de Extensão, 7(10), 9-28. doi:10.5007/18070221.2010v7n10p9

Machado, A. C., \& Bello, S. F. (2015). Habilidades sociocomunicativas e de atenção compartilhada em bebês típicos da primeira infância. Revista Psicopedagogia, 32(98), 150-157. http://www.revistapsicopedagogia.com.br/exportarpdf/41/v32n98a05.pdf

Martins, C., \& Kortmann, G. L. (2015). Recorte da experiência psicopedagógica clínica: Possibilidades de aplicação do Inventário Portage Operacionalizado com sujeito com transtorno do espectro autista. Diálogo, 28, 25-40. http:// revistas.unilasalle.edu.br/index.php/Dialogo/article/view/1716

Menezes, C. C., Gon, M. C. C., \& Zazula, R. (2013). Análise funcional de eventos antecedentes ao comportamento de desobediência de crianças. Psicologia: Teoria e Prática, 15(2), 19-32. http://pepsic.bvsalud.org/scielo.php?script=sci arttext\&pid $=$ S1516-36872013000200002\&lng $=p t \& t \operatorname{lng}=p t$

Morais, F. D., Freitas, J. C., Viana, F. P., \& Formiga, C. K. M R. (2012). Correlation between neurofunctional profile and sensory-motor skills of children with cerebral palsy. Journal of Human Grown and Development, 22(2), 226-232. http:// pepsic.bvsalud.org/scielo.php?script $=$ sci isoref\&pid $=\mathrm{S} 0104$ $12822012000200015 \& \operatorname{lng}=\mathrm{pt} \& \operatorname{tlng}=\mathrm{pt}$

Murta, A. M. G., Lessa, A. C., Santos, A. S., Murta, N. M. G., \& Cambraia, R. P. (2011). Cognição, motricidade, autocuidados, linguagem e socialização no desenvolvimento de crianças em creche. Revista Brasileira de Crescimento e Desenvolvimento Humano, 21(2), 220-229. http://pepsic.bvsalud.org/scielo. php?script=sci arttext\&pid=S0104-12822011000200005\&ln $\mathrm{g}=\mathrm{pt} \& \mathrm{t} \operatorname{lng}=\mathrm{pt}$

Nicolielo, A. P., Gonçalves, B. L. R., Arruda, J. M. P., \& Lopes-Herrera, S. A. (2014). Intervenção fonoaudiológica baseada na perspectiva comportamental em transtorno global do desenvolvimento (TGD): Relato de caso. Revista CEFAC, 16(4), 1351-1360. http://dx.doi.org/10.1590/19820216201423812

Oliveira, A. I., Garotti, M., \& Sá, N. M. C. M. (2008). Tecnologia de ensino e tecnologia assistiva no ensino de crianças com paralisia cerebral. Ciências e Cognição, 13(3), 243-262. http:// www.cienciasecognicao.org/revista/index.php/cec/article/ view/78

Pereira, V. A., Chiodelli, T., Rodrigues, O. M. P. R., Silva, C. S. O., \& Mendes, V. F. (2014). Desenvolvimento do bebê nos dois primeiros meses de vida: Variáveis maternas e sociodemográficas. Pensando Famílias, 18(1), 64-77. http:// pepsic.bvsalud.org/scielo.php?script $=$ sci arttext\&pid=S1679494X2014000100007\&lng=pt\&tlng=pt

Pereira, V. A., Rodrigues, O. M. P. R., Carvalho, S. Z. L., \& Chiodelli, T. (2015). Influências do estresse e ansiedade puerperal nos primeiros meses do desenvolvimento infantil. Cadernos de Pós-Graduação em Distúrbios do Desenvolvimento, 15(1), 89-100. http://editorarevistas.mackenzie.br/index.php/cpgdd/ article/view/11279/7010

Pereira, V. A., Silva-Marinho, C. S. O., Rodrigues, O. M. P. R., Chiodelli, T., \& Donatto, M. L. (2015). Investigação de fatores considerados de risco para o desenvolvimento motor de lactentes até o terceiro mês. Pensando Famílias, 19(2), 73-85. http://pepsic.bvsalud.org/scielo.php?script=sci arttext\&pid=S1679-494X2015000200007\&lng=pt\&tlng=pt

Peres, R. C. N. (2004). O lúdico no desenvolvimento da criança com paralisia cerebral espástica. Revista Brasileira de Crescimento e Desenvolvimento Humano, 14(3), 37-49. http://dx.doi. org/10.7322/jhgd.40114

Postalli, L. M. M., Munuera, R. F., \& Aiello, A. L. R. (2011). Caracterização de família de mãe com deficiência intelectual e os efeitos no desenvolvimento dos filhos. Revista Brasileira de Educação Especial, 17(1), 37-52. http://dx.doi.org/10.1590/ S1413-65382011000100004

Prado, M. T.A., Fell, R. F., Salmazo, A. S., Gomes, G. C.C., Silva, M. S., Santos, S. M. T., \& Fernani, D. C. G. L. (2012). Avaliação do crescimento e desenvolvimento de crianças por meio do Inventário Portage Operacionalizado. Colloquium Vitae, 4(1),10-17. http://revistas.unoeste.br/revistas/ojs/index. $\mathrm{php} / \mathrm{cv} / \mathrm{article} / \mathrm{view} / 535$

Robles, H. S. M., \& Gil, M. S. C. A. (2006). O Controle instrucional na brincadeira entre crianças com diferentes repertórios. Psicologia: Reflexão e Crítica, 19(2), 197-205. https://dx.doi. org/10.1590/S0102-79722006000200005

Rocha, S. R., Dornelas, L. F., \& Magalhães, L. C. (2013). Instrumentos utilizados para avaliação do desenvolvimento de recém-nascidos pré-termo no Brasil: Revisão de literatura. Cadernos de Terapia Ocupacional da UFSCar, 21(1), 109-117. http://dx.doi.org/10.4322/cto.2013.015

Rodrigues, O. M. P. R. (2009). O Inventário Portage Operacionalizado e o desenvolvimento de bebês [Tese de livre docência, Universidade Estadual Paulista]. Repositório da UNESP. https://repositorio.unesp.br/handle/11449/116074

Rodrigues, O. M. P. R. (2012). Escalas de desenvolvimento infantil e o uso com bebês. Educar em Revista, 43, 81-100. http://dx.doi. org/10.5380/educar.v0i43.26405

Rodrigues, O. M. P. R., \& Bolsoni-Silva, A. T. (2011). Efeitos da prematuridade sobre o desenvolvimento de lactentes. Revista Brasileira de Crescimento e Desenvolvimento Humano, 21(1),111-121. http://pepsic.bvsalud.org/scielo. php?script=sci_arttext\&pid=S0104-12822011000100011\&ln $\mathrm{g}=\mathrm{pt} \& \operatorname{tlng}=\mathrm{pt}$

Rodrigues, O. M. P. R., \& Carnier, L. E. (2007). Avaliação do desenvolvimento geral de crianças de um a cinco anos de idade contaminadas por chumbo. Interação em Psicologia, 11(2), 269-279. http://revistas.ufpr.br/psicologia/article/ download/11610/8148

Rodrigues, O. M. P. R., \& Nunes, C. O. A. T. (2009). Desenvolvimento infantil e a contaminação por chumbo: Análise das defasagens observadas. Revista Salus, 3(1),15-22. http://www.revistas. unicentro.br/index.php/salus/article/download/1199/1164

Rodrigues, B. G. S., Silva, J. L. O., Guimarães, P. G., Formiga, C. K. M. R., \& Viana, F. P. (2015). Evolução de uma criança com síndrome de Treacher Collins em tratamento fisioterapêutico. Fisioterapia em Movimento, 28(3), 525-533. http://dx.doi. org/10.1590/0103-5150.028.003.AO11 
Rossi, N. F., Gatto, A. R., Cola, P. C., Souza, D. H., Moretti-Ferreira, D., \& Giacheti, C. M. (2009). Oropharyngeal dysphagia and language delay in partial trisomy 9p: Case report. Genetics and Molecular Research, 8(3), 1133-1138. http://www.ncbi. nlm.nih.gov/pubmed/19866432

Sandroni, G. A., Ciasca, S. M., \& Rodrigues, S. D. (2015). Avaliação da evolução do perfil motor de pré-escolares com necessidades educativas especiais após intervenção psicomotora breve. Revista Psicopedagogia, 32(97), 4-13. http://pepsic. bvsalud.org/scielo.php?script $=$ sci_arttext\&pid=S0103$84862015000100002 \& \operatorname{lng}=\mathrm{pt} \& \mathrm{t} \operatorname{lng}=\overline{\mathrm{pt}}$

Scalha, T. B., Souza, V. G., Boffi, T., \& Carvalho, A. C. (2010). A importância do brincar no desenvolvimento psicomotor: Relato de experiência. Revista de Psicologia da UNESP, 9(2), 79-92. https:// seer.assis.unesp.br/index.php/psicologia/article/view/518/474

Shamseer, L., Moher, D., Clarke, M., Ghersi, D., Liberati, A., Petticrew, M., Shekelle, P., Stewart, L. A., \& PRISMA-P Group. (2015). Preferred reporting items for systematic review and meta-analysis protocols (PRISMA -P) 2015: Elaboration and explanation. BMJ 2015(349), g7647 doi: http://dx.doi. org/10.1136/bmj.g7647

Silva, N. C. B., \& Aiello, A. L. R. (2012). Ensinando o pai a brincar com seu bebê com síndrome de Down. Educar em Revista, 28(43), 101-116. http://revistas.ufpr.br/educar/article/ view/26406

Silva, E. C., Formiga, C. K. M. R., \& Viana, F. P. (2009). Avaliação da função motora grossa e do desenvolvimento de uma criança com síndrome de Lennox-Gastaud em tratamento de reabilitação. Revista Movimenta, 2(4), 159-164. http://revista. ueg.br/index.php/movimenta/article/view/7229

Silva, D. B. R., \& Martinez, C. M. S. (2002). Modelos de avaliação em Terapia Ocupacional: Estudo dos hábitos funcionais e de autossuficiência em crianças. Cadernos Brasileiros de Terapia Ocupacional, 10(2), 77-93. http://www. cadernosdeterapiaocupacional.ufscar.br/index.php/cadernos/ article/view/210

Sousa, N. M., Souza, C. B. A., \& Gil, M. S. C. A. (2013). Aprendizagem Rápida de Comportamento de Ouvinte por um
Bebê. Interação em Psicologia, 17(1), 67-78. http://revistas. ufpr.br/psicologia/article/view/28205

Suehiro, A. C. B., Benfica, T. S., \& Cardim, N. A. (2015). Avaliação cognitiva infantil nos periódicos científicos brasileiros. Psicologia: Teoria e Pesquisa, 31(1), 25-32. http://dx.doi. org/10.1590/0102-37722015011755025032

Taira, J. S., Kawaguchi, T. S., \& Bofi, T. C. (2009). A reeducação psicomotora na criança com baixa visão associada à diparesia espástica. Temas sobre Desenvolvimento, 17(97), 37-41.

Taques, D. C. S. R., \& Rodrigues, O. M. P. R. (2006). Avaliação do repertório comportamental de bebês nos quatro primeiros meses de vida: Uma proposta de análise. Revista Brasileira de Crescimento e Desenvolvimento Humano, 16(2), 77-87. http:// pepsic.bvsalud.org/scielo.php?script=sci_arttext\&pid=S0104$12822006000200008 \& \operatorname{lng}=$ pt\&tlng=pt.

Vieira, M. E., Ribeiro, F. V., \& Formiga, C. K. M. R. (2009). Principais instrumentos de avaliação de desenvolvimento da criança de zero a dois anos de idade. Revista Movimenta, 2(1), 23-31. https://edisciplinas.usp.br/pluginfile.php/3329596/ mod resource/content $/ 0 /$ instrumentos $\% 20 \mathrm{de} \% 20$ avalia $\%$ C3\%A7\%C3\%A3o\%20do\%20DI\%200\%20a\%20 $2 \% 20$ anos.PDF

Zerbeto, A. B., Cortelo, F. M., \& Élio Filho, B. C. (2015). Association between gestational age and birth weight on the language development of Brazilian children: A systematic review. Jornal de Pediatria, 91(4), 326-332. http://dx.doi. org/10.1016/j.jped.2014.11.003

Windholz, M. H. (2016). Passo a passo, seu caminho: Guia curricular para o ensino de habilidades básicas $\left(2^{\mathrm{a}}\right.$ ed. revista e ampliada). EDICON.

Williams, L. C. A. (1983). Favorecendo o desenvolvimento de crianças excepcionais em fase pré-escolar através de treino dado a seus familiares no ambiente natural [Tese de doutorado não publicada]. Universidade de São Paulo.

Williams, L. C. A., \& Aiello, A. L. R. (2001). O Inventário Portage Operacionalizado: Intervenção com famílias. Memnon; FAPESP. 